\title{
THE ROLE OF THE HEALING GARDENS ELEMENTS IN PEDIATRIC HOSPITAL TO CULTIVATE A MORE 'COGNITIVE AND SENSORY SPACES'
}

\author{
*Heba Adel Ibrahim khodier, Lamis Saad El-Din El-Gezawy and Heba Mohamed Abdo \\ Department of Architecture, Mansoura University Faculty of Engineering, Egypt. \\ *Corresponding author E-mail: hebade192@gmail.com,
}

\begin{abstract}
The use of healing gardens in pediatric hospitals has been increased since it has proved that it has a psychological and cognitive impact on children.Therefore, this paper discusses the design elements of healing gardens in medical environments and how it reflects on the children perception and psychological recovery. The paper intended to prove that relevance between the healing gardens elements and cognition behavior of hospitalized, and if so, how to use these elements to enhance children preception?

Conclusion in this paper can be determined as a step toward cognitive and sensory outdoor spaces in pediatric hospitals.

KEY WORDS: Healing Garden, Sensory Gardens, Design Principles, Cognitive Performances, Psychological Recovery.

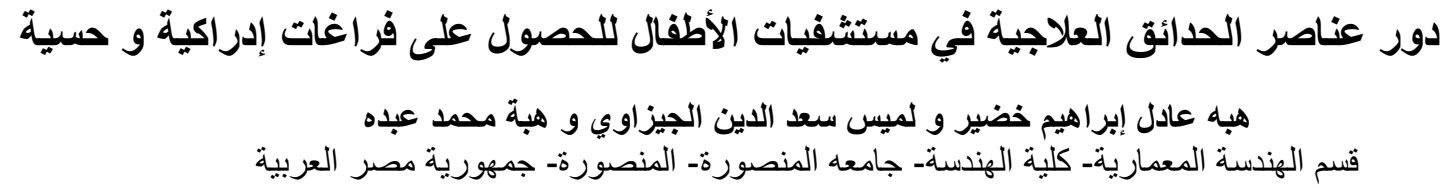

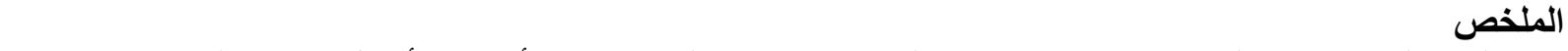

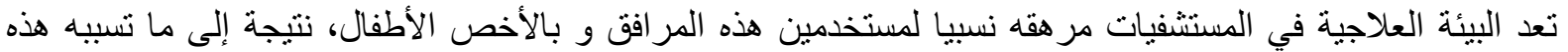

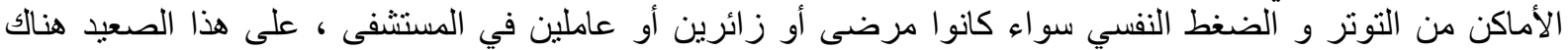

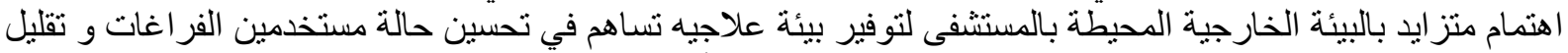

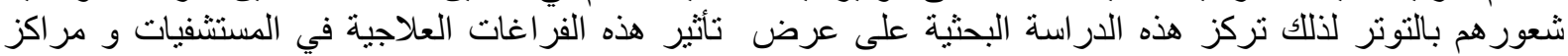

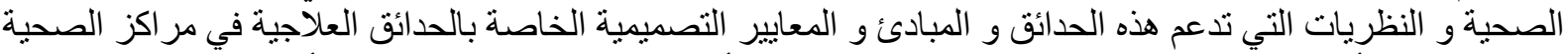

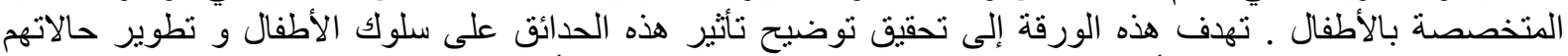

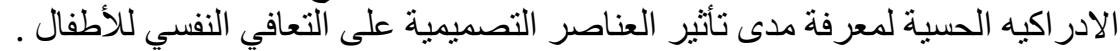

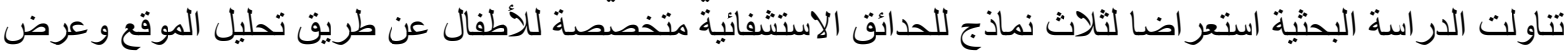

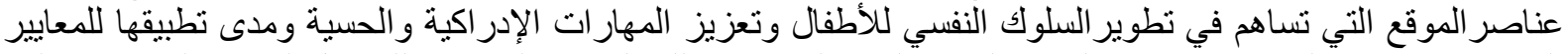

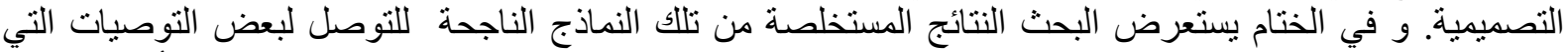
تساعد في تفعيل و الاهتمام بالبيئة الخارجية المحيطة في المستشفيات و المر اكز الصحية مما يؤدي الصئ اللي تحسين الأداء المعرفي و الحسي وتعزيز التعافي النفسي للأطفال.

الكلمات المفتاحية: الحدائق الاستثفائية ، الحدائق الحسية، الاعتبارات التصميمية للحدائق العلاجية، الأداء المعرفي، 1 لشفاء النفسي. 


\section{INTRODUCTION:}

The healing tools in medical environment were neglected in the last centuries where medicine takes the main concern in the treatment of disease. However, there are many evidences expose that healing gardens in hospitals contribute with the healing process (Ulrich R. S., 1999).

Through the development of healing gardens in hospitals they devote considerably the healing elements to create a satisfied environment which help pediatric patients to heal as soon as possible, shorten the hospitalization and recovery duration, effect on children psychological part such as mitigate anxiety and stress, provide the cognitive restoration and promote body and mental health. Healing garden in pediatric hospital has a special importance because the children have the ability to interact with the surrounding environment more than the others, so they need particular activities and settings to provide spaces to accommodate their needs (Huisman, 2012).

\section{METHODOLOGY:}

In an attempt to highlight the role of the healing elements in pediatric hospital to provide more cognitive spaces and rich sensory medical environment, by reviewing the main important elements and their method of use in a number of case studies:

Analysis of the outdoor spaces of three pediatric hospital as shown in Table 1 through site analysis and review of the healing elements that were used in order to provide a sensory experience and improve cognitive and behavioral abilities of children.

Table 1 The three selected case studies.

\begin{tabular}{|l|l|}
\hline Case study 1 & Nemours Children's Hospital, Orlando, Florida, USA \\
\hline Case study 2 & $\begin{array}{l}\text { The Crown Sky Garden: Ann \& Robert H. Lurie Children's Hospital } \\
\text { of Chicago }\end{array}$ \\
\hline Case study 3 & Nelson Mandela Children's Hospital architecture, South Africa \\
\hline
\end{tabular}

\section{HEALING GARDENS DESIGN ELEMENTS FOR PEDIATRIC HOSPITALS.}

\subsection{Hard landscape in pediatric hospitals:}

\subsubsection{Gateways and entrances:}

Ought to be welcomed for patients and users through using interesting and colorful plants and also, adding work of arts can make a feeling of the place and organize the first impression and focuses. In addition, utilize with signage to ease finding the way around the hospital (Shackell, Aileen and Walter, Robin, 2012).

\subsubsection{Paths:}

one of primary elements in the healing garden is direct paths Moreover, paths should be simple, consistent finishes and also avoided right angle corners, and to prevent slipping in slops should be designed not exceed 1120 and with a minimum wide $1.2 \mathrm{~m}$ for wheelchair access as shown in Figure 1. Hand rails should thoughtfully arrange along the pathway to help users to balance and support themselves while walking through the gardens as in Figure 2 (Estates, 2005). 


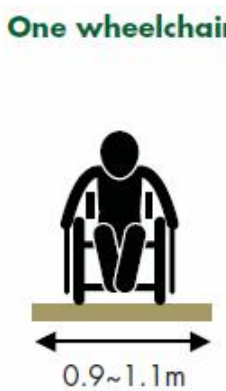

Figure 1 Pavement wid ths to support wheelchair access (Wilson $\mathrm{R} ., 2007$ )

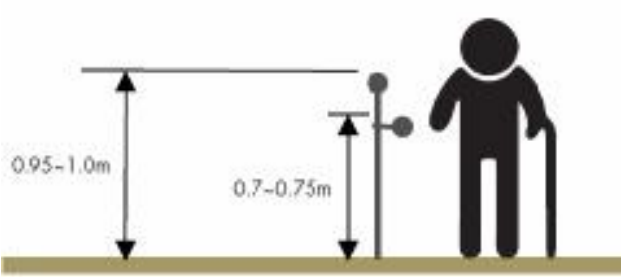

Figure 2 Recommended height for hand rails

(Wilson R. , 2007)

\subsubsection{Site furniture:}

\section{A-Seating (John Wiley \& Sons Main, 2010):}

- The garden should has vary choices of seats which provide sunny and shaded seats or ordinarily and movable seats.

- Seats ought to be comfortable with armrests with a minimum width of $0.1 \mathrm{~m}$ as in Figure 3.

- Provide appropriate distance with a minimum width of $0.6 \mathrm{~m}$ between paving and seat Figure 4.
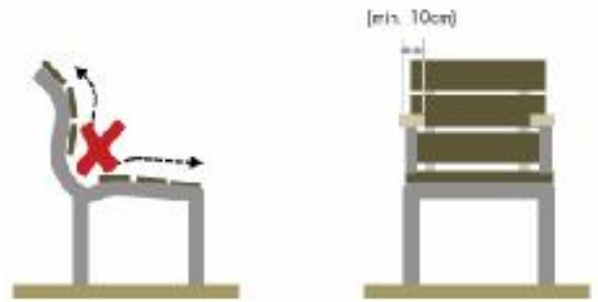

Figure 3 Avoid benches with slumped backs Armrest should be min.0.1m width (Wilson $R_{0}$, 2007)

B-Signage (Arthur, P. and Passini, $R, 1992$ ):

- Should be Fitting and help to understand routes and passages such as directions, activities \& parking areas. Figure 5

- The signs material ought to be clear, catching the attention and pleasant.

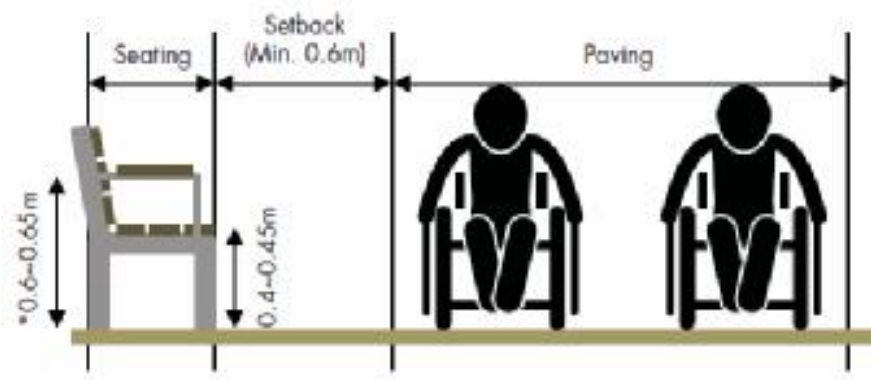

Figure 4 Distance of setback between seating and paving

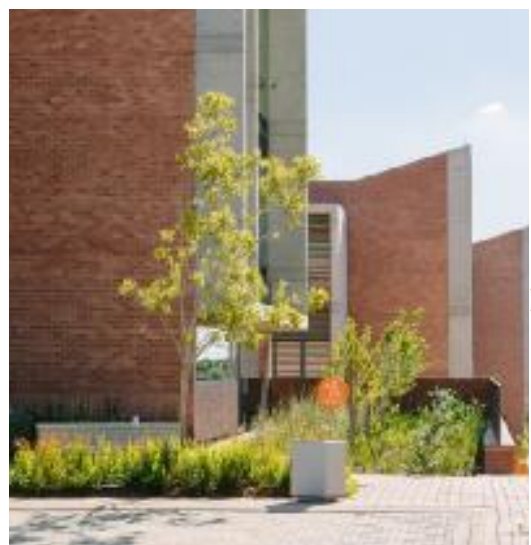

Figure 5 signage in the garden should be visible from afar and remains unobstructed Nelson Mandela , South Africa. (Emily Martin, 2017 ) 
- For children it should be settled in approximate height of $1.2 \mathrm{~m}$ to be appropriate for them and for disabled users it is a must to use sensible signs such as Braille textural markers, sounds of water and wind chimes.

\section{C-Lighting (Marcus C. a., 2013):}

- Sunlight helps improve children's motor skills, decrease physiological fatigue, vitamin D synthesis and overall improved performance so the consideration of offering spaces where children are exhibited to sunlight is not questionable.

- The lighting should be placed in changing levels of corridors such as slopes and stairs, not only to add aesthetic look but also to avoid accidental falls, enhance the sense of safety and improve wellbeing.as in Figure 6.

\subsubsection{Children's play areas (Wilson R. ,}

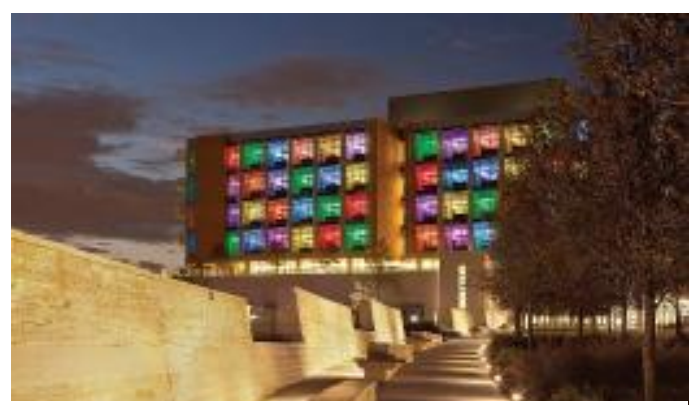

Figure 6 using lights in slops through the walking rout in Nemours Children's

Hospital , Orlando, Florida, USA. (networks, 2014)

\section{7):}

- Children often feel stress and tension while being in the hospital environment because they feel controlled therefore it's important to afford to them spaces where they can feel free to play and move.

- considerations to design secure and attractive outdoor spaces (Harris, 2011):

1- Zoning: the good utilizing to provide different activity and spaces.

2- Seating: movable seats important for socializing.

3- Shelter: to in rich their seasonal variation experience.

4- Engaging children regardless their condition of health: there might be platforms so they can move safely onto and off play structures as shown in Figure 8.

5- Variety and diversity: for instance, interesting physical environment, support playing with the natural elements (sand, water, plants), encourage movement and exercise, using colorful materials. As shown in Figure 7.

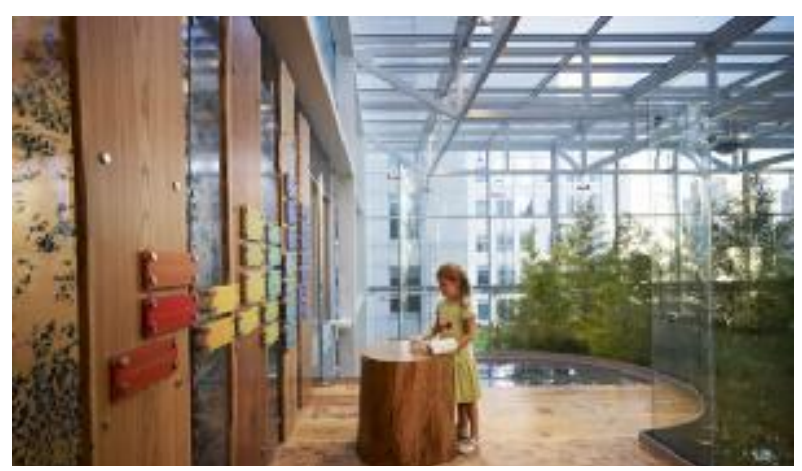

Figure 8 Tree House, is a place for children with serious immune deficiency conditions that prevent them to enter the main play area, Crown Sky Garden, Chicago (Lurie, 2017)

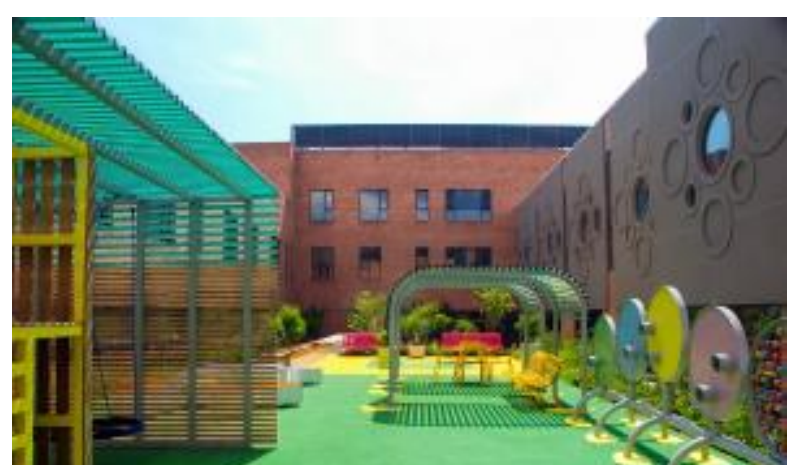

Figure 7 the space include climbing structure, seats and chalk board structure in Nelson Mandela Children's Hospital, Johannesburg, South Africa (Emily Martin, 2017) 


\subsubsection{Art (Bishop, Kate, 2012):}

- Artworks should be integrated and fit into the garden, as it can add a unique positive message and engaging focal point for the garden; complex or abstract forms of art is therefore not suitable for this kind of setting.

- The appropriate messages that artwork may impart is hope, energy, comfort and security.

- Benefits of Artworks as it form a part of the healing environment: reduce stress, improve the creative abilities of patients, create a bond between patient and care-giver, educate and be integral to wayfinding.

- Forms: Artwork may be expressed in many forms such as paintings, murals, prints, photographs, sculptures, decorative tiles, ceramics, textile hangings and furniture.

- Current practice of many healthcare facilities used to employ an artist in residence in order to handle and manage art activities which help to add sense of locality and special identity to the works of art.

- For example in Figure 9 Nemours children's hospital, Florida the mosaic panel wall designed by near to 480 children displayed in the outside recreation deck which add engaging focal point for a hospital space. (networks, 2014) In Figure 10 in Nelson Mandela Children's Hospital, Johannesburg, South Africa Small vignettes (laser cut from mild steel) were designed by children \& 20 local artists during a workshop and have been inserted into the circular components of the screen existing in the garden, to provide many moments of discovery and amusement(Emily Martin, 2017 ).

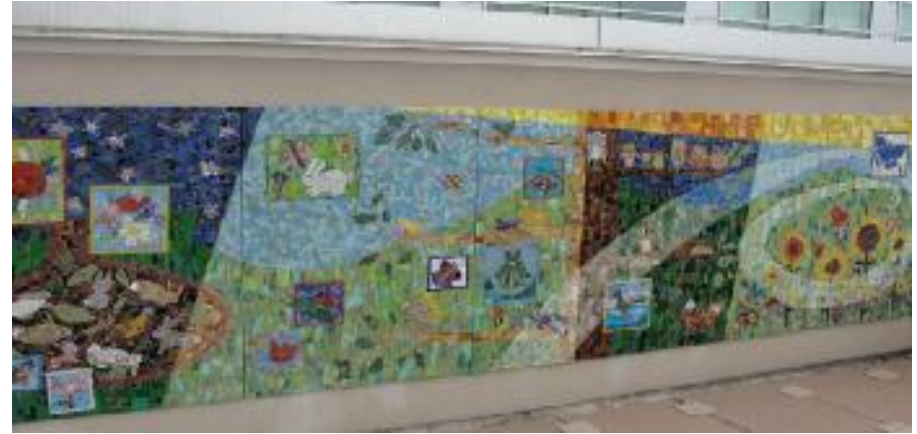

Figure 9 OUR GARDEN HOME mosaic panel is displayed in Nemours children's hospital..

\section{3-1-6 Water (Verderber S. a., 2006)}

- Benefits: running water sounds, the reflect of sun on the fountains and ponds and seeing fish in the lakes lend many positive impact on children such as:

1. Calming and engaging effect on children as in Figure 11.

2. Mask noises from the surrounding external spaces.

3. Enrich the sensory experience and add focal points for the garden to appeal all ages and abilities of children

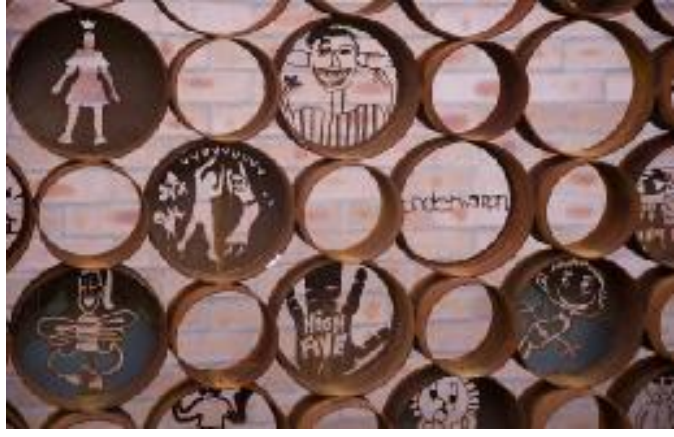

Figure 10 small vignettes in Nelson Mandela hospital.

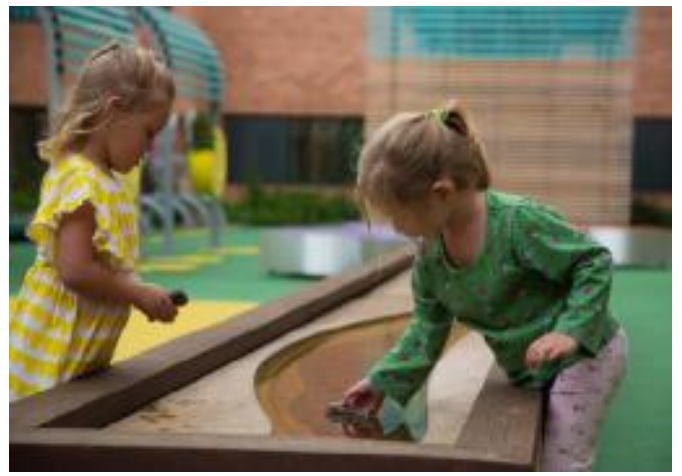

Figure 11 raised interactive water element in nelson Mandela children's hospital, South Africa. (Grif iths, 2017) 
4. On the environmental side, using waterefficient and low-maintenance landscaping is sustainable and cost-effective, with recycling and managing storm water runoff in the garden. (Furgeson, Molly., 2019).

- Usages:

1. Water engaged to the garden site in a paved area to avoid muddying.

2. Water it can be used outdoor and indoor. Indoor and atria in hospital when there is no convenient outdoor space or climate rule out using the outdoors for much of year

3. "Bubble fountains" may be more appropriate for children, as they are tactile, they use shallow water and they are designed to prevent a child

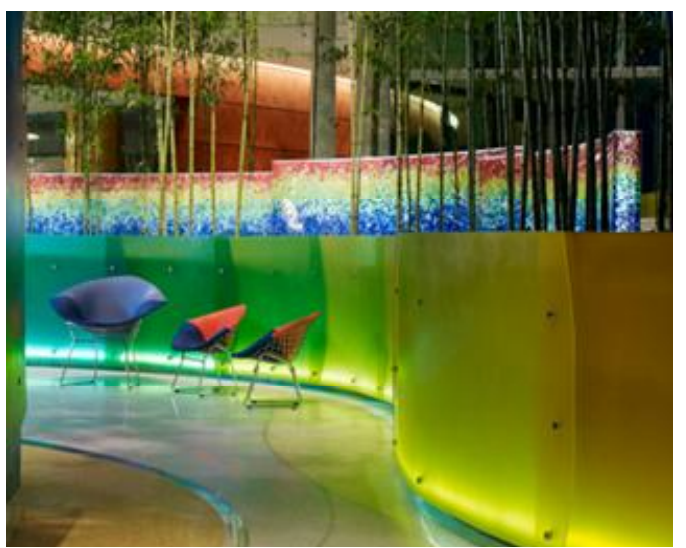

Figure 12 marble bubble fountain in Crown sky garden in Chicago (RoSPA, 2000) falling or running on it as in Figure 12

\subsection{Plants:}

As plants have the power to appeal children to discover and learn, plants and trees should be used in appropriate way as follow:

\section{3-2-1 mature trees:}

Mature trees create shade; in addition it can also append a symbolic sense of longevity and a character to the garden. For instance large canopy trees in summer it provides shade and in winter it provides shelter; they can help adjust the climate (Marcus C. a., 2013).

\section{3-2-2 plant selection (Shackell A. a., 2012):}

Various characteristics applied to select plants for a pediatric healing garden such as:

1- Color: warm colors invigorate the mind and thrill the senses while cool colors for relaxation.

2- Texture: plants with attractive leaf textures are often fascinate children through their sense of touch.

3- Smell: scents through the perfume of flowers can evoke memories by enhancing sense of smell. Fragrance can also be released through crushing and rubbing of leaves.

4-Auditory: when the breeze goes through leaves and foliage's causing gentle rustling sound may create a soothing and relaxing experience.

5- Attracting plants: plants that attract butterflies and birds.

6- Edibles: herbs and spices, fruits and vegetables can also engage children senses.

8- Plant Efficiency: Plants which tolerate climate and urban environment changes and require little water should take a priority in garden planning.

\section{3-2-3 avoided plants to use:}

Flowers with strong scent avoided for chemotherapy patients, plants with spikes and sharp thorns and plants that attract undesirable habitat.

\section{3-2-4 Contrast in composition:}

Use plants with contrasting colors, densities, leafs texture and size in compatible way to attract children.

\section{3-2-5 Plant labels:}

Interactive identification labels and educational signage for plants will inform children with interesting information.

\section{3-2-6 Planter (Leibrock, 2011):}

Elevated gardens: is a vertical gardens that can be used by both seated and ambulatory patients;

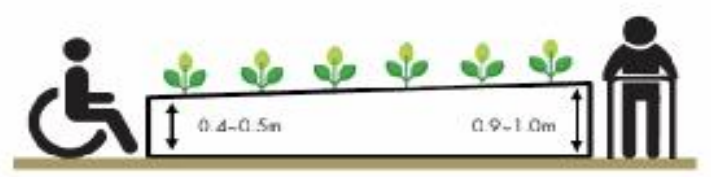

Figure 13 Recommended height for raised planter boxes. 
raised planter boxes should be designed at minimum height $0.61 \mathrm{~m}$ and the width should be $1.5 \mathrm{~m}$ if they can be accessed from all sides, or $0.75 \mathrm{~m}$ if they are used from one side.

\section{SENSORY DIMENSIONS (EPSTEIN, 2006):}

When healing garden elements of hard landscaping and plants are selected in appropriate way to appeal children senses the garden called sensory garden with the aim of offering a richer and more therapeutic to develop an overall theme of sensory interest to heightened sight, smell, hearing, touch, and taste. In medical environments sensory gardens can serve many functions such as healing, socializing, and horticultural therapy.

\subsection{Design elements that appeal the child senses (Marcus C. C., 2000):}

The human senses are active perceptual systems, which can function independently or in combination, interacting with the surrounding environment to extract information.

Table 2 design elements encouraging the development of certain sensory abilities.

\begin{tabular}{|c|c|c|c|c|}
\hline Sight & Sound & Smell & Touch & Taste \\
\hline $\begin{array}{c}\text { Color } \\
\text { Light and shadow } \\
\text { visual texture } \\
\text { form } \\
\text { movement }\end{array}$ & $\begin{array}{c}\text { Natural sounds } \\
\text { activated sounds }\end{array}$ & $\begin{array}{c}\text { Plants } \\
\text { Other smells }\end{array}$ & $\begin{array}{c}\text { Texture plants } \\
\text { Water } \\
\text { sand }\end{array}$ & $\begin{array}{c}\text { Edible fruits, } \\
\text { vegetables, herbs, } \\
\text { and spices. }\end{array}$ \\
\hline & & & & \\
\hline
\end{tabular}

\subsection{Case studies of some healing gardens:}

The main aim of presenting case studies of sensory experience in healing garden is to show that the design of spaces, with sensitive lighting, color, sound attenuation, texture and material specification are essential to the child's immediate well-being, healing process and ultimate outcome.

\section{CASE STUDY (1): Nemours Children's Hospital, Orlando, Florida, USA}

\begin{tabular}{||l||l|l|}
\hline $\begin{array}{c}\text { Discriptio } \\
\text { (Matamban } \\
\text { adzo, 2013) }\end{array}$ & $\begin{array}{l}\text { Sensory rooms that located at the north end of } \\
\text { discovery garden are designed to relax, simulate } \\
\text { and teach children Figure 14. }\end{array}$ \\
$\begin{array}{l}\text { At the end of the exploring walking trial that has } \\
\text { been restored with a combination of native } \\
\text { grasses and perennials trees there is a restoring } \\
\text { view to a large pond. as shown in Figure 15 }\end{array}$ \\
\hline $\begin{array}{l}\text { Benefits } \\
\text { (Komiske, }\end{array}$ & $\begin{array}{l}\text { Encourage children to interact with their } \\
\text { surroundings using their senses through play } \\
\text { and learn. } \\
\text { Assist in rehabilitation process of children. } \\
\text { Appeal the five senses (sight, sound, touch, } \\
\text { taste, and smell). } \\
\text { Reduce stress. }\end{array}$ & $\begin{array}{l}\text { Figure } \\
\text { rooms designed to encourage } \\
\text { children five senses, Nemours } \\
\text { Pediatric } \\
\text { Orlando,Florida,USA }\end{array}$ \\
\hline
\end{tabular}




\begin{tabular}{|c|c|c|}
\hline Elements & $\begin{array}{l}\text { Include a stream, bridges, glider benches beneath } \\
\text { arbors, and site furnishings including benches, } \\
\text { planters, large umbrellas for shade. }\end{array}$ & . \\
\hline $\begin{array}{l}\text { Sensory } \\
\text { Experien } \\
\text { ce and } \\
\text { Overall } \\
\text { Cognitive } \\
\text { Restoratio } \\
\text { n } \\
\text { As shown } \\
\text { in Figure } \\
16 \\
\text { (system, } \\
2011) \\
\text { (Ha, } \\
2014)\end{array}$ & $\begin{array}{l}\text { Sight: } \\
\text { 1- Using an enormous of bright colors in site } \\
\text { furnishings } \\
\text { 2- An extensive palette of plants and trees with } \\
\text { a seasonal interest that add and introduce } \\
\text { vivid colors to the garden. } \\
\text { Smell: using fragrant plants and herbs. } \\
\text { Touch: the garden filled with a large number of } \\
\text { textured plants and furniture that children can } \\
\text { explore. } \\
\text { Sounds: } \\
\text { 1. Using sound elements such as the xylophone } \\
\text { benches and free-standing drums to create } \\
\text { music. } \\
\text { 2. Using ornamental grasses that can add } \\
\text { soothing sound when winds go through } \\
\text { them. }\end{array}$ & $\begin{array}{l}\text { Figure } 15 \text { while walking through } \\
\text { the trail and exploring the } \\
\text { natural landscape there is a large } \\
\text { pond in the end of path. }\end{array}$ \\
\hline $\begin{array}{c}\text { Sensory } \\
\text { Experien } \\
\text { ce and } \\
\text { Overall } \\
\text { Cognitive } \\
\text { Restoratio } \\
\text { n, SOURCE } \\
\text { BY THE } \\
\text { RESEARCH } \\
\text { ER }\end{array}$ & 7) & End \\
\hline
\end{tabular}




\section{CASE STUDY (2): The Crown Sky Garden: Ann \& Robert H. Lurie Children's Hospital} of Chicago.

Description $\mid$ Crown Sky Garden is a garden

(RoSPA, situated inside a glass

2000) greenhouse.

On the twenty-third floor of the

Ann \& Robert H. Lurie

Children's Hospital of Chicago.

خطأ! لم يتم العثور على مصدر As in

المرجع. - - ان

- This project provides a new aspect in medical environment design.

- The garden consists of a variety of tools to enhance the child senses and interact with nature.

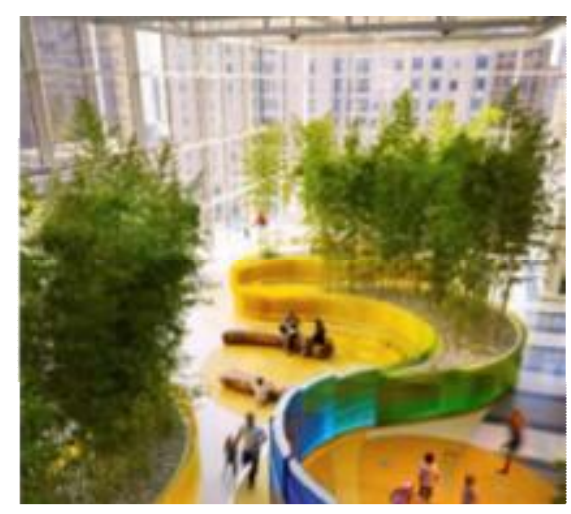

Figure 17 crown sky garden is a garden inside a glass greenhouse. 


\begin{tabular}{|c|c|}
\hline \multicolumn{2}{|c|}{ CASE STUDY (3): Nelson Mandela Children's Hospital architecture - South Africa. } \\
\hline $\begin{array}{l}\text { Descriptio } \\
\text { n } \\
\text { (Obiozo, } \\
\text { 2014) }\end{array}$ & $\begin{array}{l}\text { The hospital consist of } 5 \text { internal landscaped courtyards which provide the } \\
\text { opportunity to exposure to natural and green spaces in the outdoor environment and } \\
\text { considered as the 'green heart' of the hospital. } \\
\text { The courtyards } \\
\text { have been } \\
\text { grouped into } \\
\text { (Active and } \\
\text { Passive) healing } \\
\text { courtyards and } \\
\text { have been } \\
\text { determined by } \\
\text { the type of user } \\
\text { and its location. } \\
\text { Figure } 18 \text { Nelson Mandela Children's hospital master plan. }\end{array}$ \\
\hline $\begin{array}{l}\text { Benefits } \\
\text { (Nishii, } \\
\text { 2011) }\end{array}$ & $\begin{array}{l}\text { Gives the child the opportunity to actively participate in the cycle of nature. } \\
\text { Various elements incorporated to Design that could appeal to all five senses } \\
\text { (sight, sound, touch, taste, and smell). }\end{array}$ \\
\hline Elements & $\begin{array}{l}\text { Play elements, water features, variety of seating, colorful rubber floors and wide } \\
\text { range of plants (Ruxwana, 2010). }\end{array}$ \\
\hline $\begin{array}{l}\text { Overall } \\
\text { Cognitive } \\
\text { Restoratio } \\
\text { n } \\
\text { (magazine, } \\
\text { 2017) }\end{array}$ & $\begin{array}{l}\text { Sight: } \\
\text { 1. Colorful flooring, furniture and plants. } \\
\text { 2. Colorful chalk board structure. } \\
\text { 3. Shaded seating area as shown in Figure } 19 .\end{array}$ \\
\hline
\end{tabular}




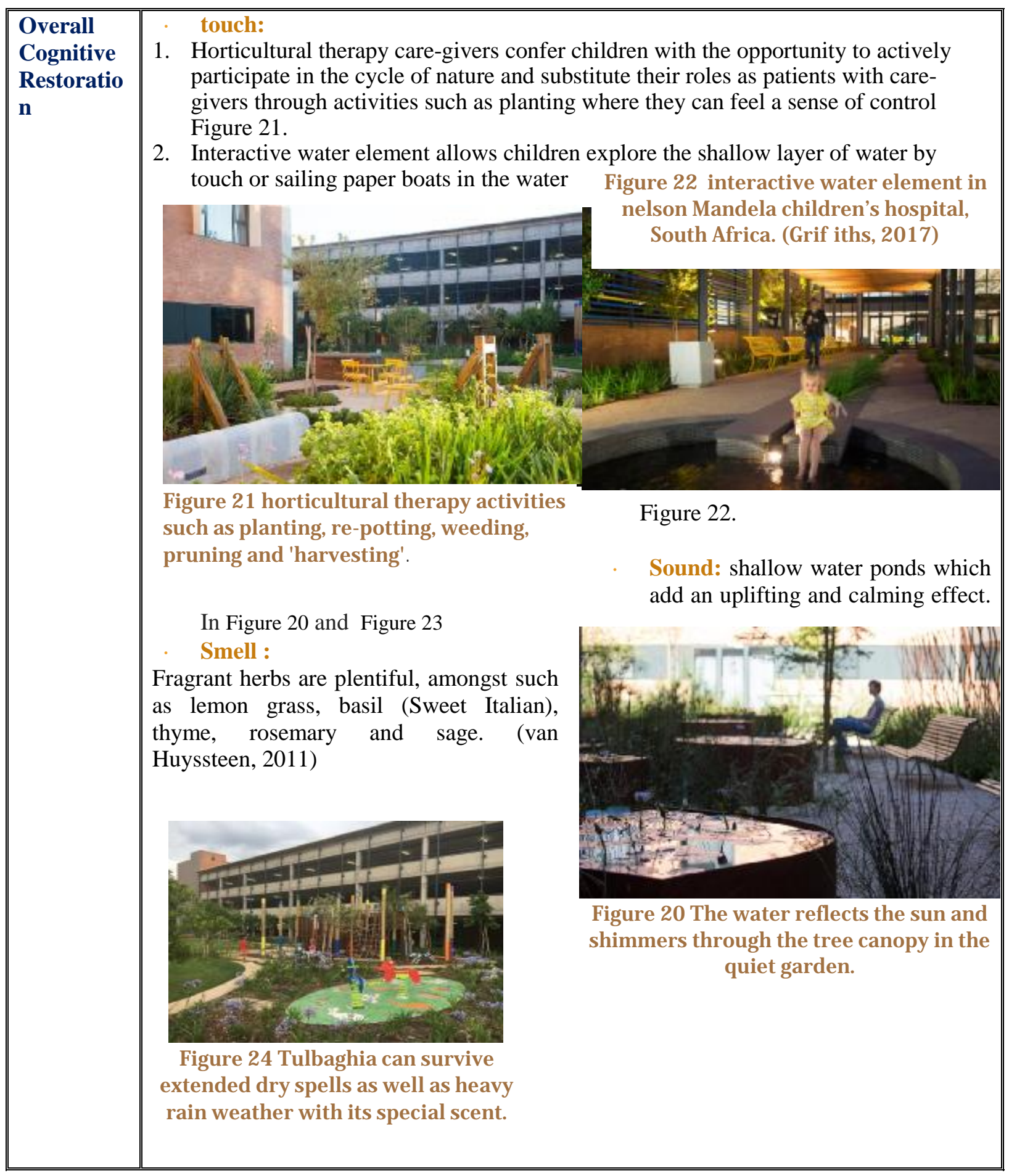




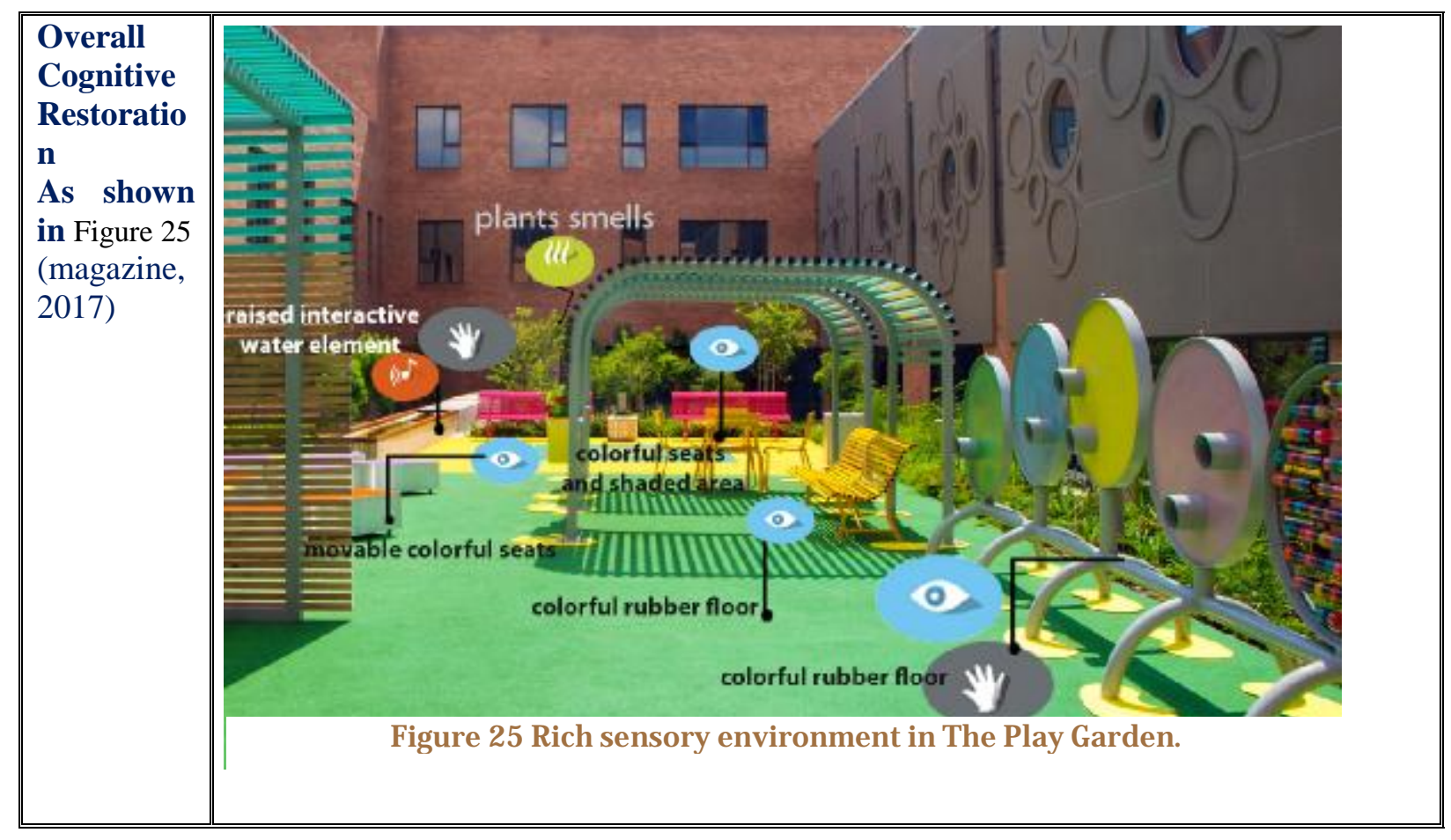

\subsection{The outcomes of applying sensory design guidelines.}

The outcomes of applying the healing elements in appropriate way for hospitalized children is important in order to engage children outdoor environment where they belong to it more than most adults so the benefits appear to be as in Table 1 (Epstein, 2006) :

Table 3 The impact of inserting healing elements on children

\begin{tabular}{|c|c|}
\hline Senses & Benefits \\
\hline $\begin{array}{l}\text { Insert elements } \\
\text { that improve } \\
\text { seeing }\end{array}$ & $\begin{array}{ll}\ddot{y} & \text { Encourage exercise. } \\
\ddot{y} & \text { Reduce physiological fatigue. } \\
\ddot{y} & \text { Overall improved performance. }\end{array}$ \\
\hline
\end{tabular}

\begin{tabular}{|c|c|c|}
\hline $\begin{array}{l}\text { Using textures } \\
\text { and materials that } \\
\text { improve touching }\end{array}$ & & $\begin{array}{l}\text { Help to identify the proximity from objects and perceive movement. } \\
\text { Helps to explore materials, items and food and understanding of } \\
\text { The surroundings. }\end{array}$ \\
\hline
\end{tabular}

\begin{tabular}{|c|c|c|}
\hline $\begin{array}{l}\text { Using of Pleasant } \\
\text { sounds that } \\
\text { improve hearing }\end{array}$ & $\begin{array}{l}\ddot{y} \\
\ddot{y} \\
\ddot{y}\end{array}$ & $\begin{array}{l}\text { Calming people and tuning them in to their environment. } \\
\text { Help to improve overall wellbeing and create sensations of } \\
\text { Pleasure affecting the limbic system. }\end{array}$ \\
\hline
\end{tabular}

\begin{tabular}{|c|}
\hline $\begin{array}{c}\text { Using materials } \\
\text { that improve } \\
\text { tasting }\end{array}$ \\
\hline $\begin{array}{l}\ddot{y} \quad \text { Taste can be a useful way of demonstrating where food comes } \\
\text { from and showing the link between growing and eating. }\end{array}$ \\
\hline
\end{tabular}




\begin{tabular}{|c|c|c|}
\hline $\begin{array}{l}\text { Using of Pleasant } \\
\text { fragrances that } \\
\text { improve smelling }\end{array}$ & $\begin{array}{l}\ddot{y} \\
\ddot{y} \\
\ddot{y} \\
\ddot{y} \\
\ddot{y} \\
\ddot{y} \\
\ddot{y}\end{array}$ & $\begin{array}{l}\text { Relax children and reduce pain. } \\
\text { Lowers blood pressure, heart rate regulation and relaxes muscles. } \\
\text { Works as positive distraction. } \\
\text { Encourage the release of endorphins, which works as powerful } \\
\text { Pain-killing hormones. } \\
\text { Evoke strong feelings and memories in order to provide mental } \\
\text { Health. }\end{array}$ \\
\hline
\end{tabular}

\section{DISCUSSIONS}

By reviewing a few recurring themes and recommendations in terms of making a space "more cognitive and sensory" for children by analyzing three case studies with divergent typology conditions of healing spaces in hospitals as shown in Table 1Table 4:

Table 4 main features for each case study.

\begin{tabular}{|c|c|}
\hline $\begin{array}{l}\text { Nemours } \\
\text { Children's } \\
\text { Hospital }\end{array}$ & $\begin{array}{l}\text { The hospital include a discovery garden with interactive sensory garden } \\
\text { rooms, as well as roof-top therapy gardens, all of which include elements } \\
\text { for playing, learning and healing. } \\
\ddot{y} \text { Outdoor environment design based on healing, respite and therapy. As a } \\
\text { result of restorative landscape to be healing and sensory as well a } \\
\text { releasable views from patient rooms, this hospital has been named "a } \\
\text { hospital in a garden". }\end{array}$ \\
\hline $\begin{array}{l}\text { The Crown } \\
\text { Sky Garden }\end{array}$ & $\begin{array}{l}\text { ÿ This garden in context of a closed covered space that brings the outdoor } \\
\text { in. } \\
\ddot{y} \text { The garden incorporates light, water, sound and wood elements to create } \\
\text { an interactive space that attract children and adults alike. } \\
\ddot{y} \text { Which offer a variety spaces for active and for resting, as well as bamboo } \\
\text { trees with playfully light displays and meandering walls add an interesting } \\
\text { experience in the garden. }\end{array}$ \\
\hline $\begin{array}{c}\text { Nelson } \\
\text { Mandela } \\
\text { Children's } \\
\text { Hospital }\end{array}$ & $\begin{array}{l}\ddot{y} \text { Offers active and passive courtyards according its location and types of } \\
\text { users. } \\
\ddot{y} \text { The courtyard was conceptualized as the heart of the building's with a } \\
\text { specific purpose to enclosure patients and their visitors to interact with } \\
\text { nature, in order to aid the process of healing, explained landscape } \\
\text { architect }\end{array}$ \\
\hline
\end{tabular}


While designing a healing garden in children healthcare facilities it should be consider the importance of specific elements in garden design that essentially impacted on children, such as:

\section{A-Seating:}

In various forms, such as with arms and backs, moveable seating or they can shape it themselves and furthermore different colors and textures of material create an amusing atmosphere through the garden attracting the attentions of children as well as improving their tactile and sighting perception.

\section{B-Pavement Material:}

Material must be non-slide and non-glare with handrails along some walkways indeed.

Colorful rubber floors through the garden that appeal children sight sense.

\section{C-Activities:}

Open air exercises can improve children perception, such as:

1- Horticultural treatment is considered as a therapeutic framework which may enhance tactile perception, evoke memory and social association.

2- Playing areas are helpful for physical and emotional wellness of children. Recommendations for play facilities that allow children to use their senses :

1- A varied and interesting physical environment (for example, things at different levels, spaces of different sizes, places to hide, and places to inspire mystery and imagination).

2- Playing with the natural elements - earth, wind, water, air.

3- Movement - for example, running, jumping, rolling, climbing and social interactions.

4- Consider the shadow patterns consequent by garden playing structure which are often fascinate children as they change shapes as the sun moves (Humbert, 2006).

3- Art involve children to do some art crafts and usefully utilized can induce their perceptions.

\section{D-Access to Nature:}

The essential aim in healing garden design is to encourage users to often directly interact with the plants. The selection of trees and plants should be in appropriate way that will thrive in the environment and provide an arranged theme design to evoke memorable experiences; Using plants, flowers, foliage's and berries that offer an interesting colors and scents throughout the different seasons. Therefore, avoid plants that are toxic, allergenic, or are likely need applying insecticide. Sensory gardens is designed for all users of the garden, including the visually impaired patients, scented and brightly colored flowers can provide an interesting sensory experience for them. Also scents can aid to evoke their memories and suddenly stimulate memories and responses. Sensory stimulation has special importance for patients with reduced cognitive function, which can be assisted by colorful flowers and plants throughout the year, scented plants such as( Lavandula spp and Echinacea spp.), and plants with tactile qualities such as Fruit trees which can offer seasonal attractions and can be a good choice for smaller spaces.

\section{CONCLUSIONS}

The medical environment in our country often implant some trees and flowers or constructing the hospital outdoor spaces with grasses and large area of ornamental lawns and hard paved squares regardless the user's needs and the value of hospital's outdoor environment. Analyzing theories and practices in our outdoor medical environments according to the proven advantages and a numerous universal awards in landscape design in order to upgrade the quality of the current outdoor environment of children's hospitals. In order, to move forward to accelerate the development of healing landscape in domestic medical environment we should evaluate the healing gardens design elements and analyze their impact of it on patients. 
Moreover identifying psychiatrist's opinions that follow patient's psychological situation and involving children during the design process will avoid flaws in the future and move on through upgrade the outdoor environments. Taking children's points of view thoughtfully and give them self-explanatory suggestions will help them to express their concerns, and allow them to participate in decision-making. Procedure used to involve children in design process can be by give them the opportunity to paint, walk through tours, photography and follow-up of their daily activities and interactions in the gardens, as they have various aspects to express their feelings.

Furthermore, architects should have a special attention and continual emphasis to integrate all design elements to create a top notch environment that support physical fitness, reduce stress and improve cognitive needs. Subsequently, there is a list of important elements which should be in mind while designing the healing gardens:

1- Microclimate concertation: which means control that local Climate (i.e., heated floor to produce warmth and misters to cool).

2- Providing an exploring trails and strolling ways.

3- Play area for children' delight.

4- Active and passive area for different exercises and contemplation region to relax.

\section{REFERENCES}

1. Arthur, P. and Passini, R . (1992). Wayfinding: People, Signs and Architecture. New York: McGraw-Hill Book Co.

2. Bishop, Kate. (2012). The role of art in a paediatric healthcare environment from children's and young people's perspectives. Procedia-Social and Behavioral Sciences, 38, 81--88.

3. Design, m. k. ( 2014). myk-d. Retrieved from mikyoung kim design : http://mykd.com/projects/crown-sky-garden/

4. Emily Martin, T. M. (2017, November 2). designcurial. Retrieved from ww.designcurial.com/projects/nelson-mandela-childrens-hospital-johannesburg

5. Epstein, M. (2006). Hospital gardens help patients heal. Seattle Daily Journal Health Care Design \& Construction, 11.

6. Estates, N. (2005). Wayfinding Effective Wayfinding and Signing Systems, Guidance for Healthcare Facilities. Stationery Office Books; 2nd edition.

7. Furgeson, Molly. (2019, 2 14). Healing Gardens. Retrieved from University of Minnesota Department of Horticultural -Science: http://www.sustland.umn.edu/design/healinggardens.html

8. Ha, J.-M. a.-B. (2014). Child-friendly Design Factors for Children's Hospital Planning. Journal of the architectural institute of Korea planning \& design, 30(10), 87--95.

9. Harris, C. A. (2011). Design Details for Health: Making the Most of Design's Healing Potential (Vol. 9). New York: John Wiley \& Sons.

10. Huisman, E. R. (2012). Healing environment: A review of the impact of physical environmental factors on users. Building and environment, 58, 70-80.

11. Humbert, M. L. (2006). Factors that influence physical activity participation among high-and low-SES youth. Qualitative health research, 16(4), 467-483.

12. John Wiley \& Sons Main, B. a. (2010). Site Furnishings: A Complete Guide to the Planning, Selection and Use of Landscape Furniture and Amenities. USA: John Wiley \& Sons,

13. Jones, D. R. (2016). The 'biophilic organization': An integrative metaphor for corporate sustainability. Journal of business ethics, 138(3), 401--416.

14. Komiske, B. K. (2013). Designing the World's Best Children's Hospitals III: The Future of Healing Environments (Vol. 3). Images Publishing.

15. Leibrock, C. A. (2011). Design details for health: making the most of design's healing potential (Vol. 9). John Wiley $\backslash \&$ Sons.

16. Lurie, A. \&. (2017). luriechildrens. Retrieved from https://www.luriechildrens.org/en/patients-visitors/explore-the-hospital/crown-skygarden/ 
17. magazine, A. D. ( 2017). +11 projects from Africa. Africa's premier digital, interactive architecture and design magazine, 9--11.

18. Marcus, C. a. (2013). Therapeutic Landscapes: An Evidence-Based Approach to Designing Healing Gardens and Restorative Outdoor Spaces. New Jersey: John Wiley and Sons.

19. Marcus, C. C. (2000). Design $\backslash \&$ Health-The Therapeutic Benefits of Design. 2nd International Congress on Design and Health. Karolinska Institute Stockholm, Sweden.

20. Matambanadzo, S. (2013). Model update Nemours Childrens Hospital . healthcare design magazine , 1-5.

21. Naylor networks, N. (2014). naylornetwork. Retrieved from ASLA Florida: http://www.naylornetwork.com/afl-nwl/articles/indexv2.asp?aid $=253078 \&$ issue ID $=36750$

22. Nemours Children's Hospital, n. c. ( 2011, September Monday 12 ). About Nemours. Retrieved from Nemours: https://www.nemours.org/about/mediaroom/press/florida/orlando/grantspending.html

23. Nishii, J. (2011). The therapeutic benefits of gardening: Cultivating health through interaction with nature. California, United States: Alliant International University.

24. Obiozo, R. A. (2014). Healing Gardens For The Construction Site: An Innovative Organisational Management Strategy. Postgraduate Conference.

25. RoSPA. (2000). Royal Society for the Prevention of Accidents. Retrieved from Factsheet: Child safety in the home.: http://www.rospa.co.uk

26. Ruxwana, N. L. (2010). ICT applications as e-health solutions in rural healthcare in the Eastern Cape Province of South Africa\}. Health information management journal, 39(1), 17--29.

27. Shackell, A. a. (2012). Greenspace Design for Health and Well-being: Practice Guide. Forestry Commission.

28. Shackell, Aileen and Walter, Robin. (2012). Green spaces design for health and well being: Practice Guide. Forestry Commission.

29. Ulrich, R. S. (1999). Effects of gardens on health outcomes: Theory and research. Healing gardens: therapeutic benefits and design recommendation, 27-86.

30. Van Huyssteen, M. a. (2011). Antidiabetic and cytotoxicity screening of five medicinal plants used by traditional African health practitioners in the Nelson Mandela Metropole, South Africa. African Journal of Traditional, Complementary and Alternative Medicines, 8(2).

31. Verderber, S. a. (2006). Innovations in Hospice Architecture. Taylor \&Francis.

32. Wilson, R. (2007). Nature and young children: Encouraging creative play and learning in natural environments. Routledge. 